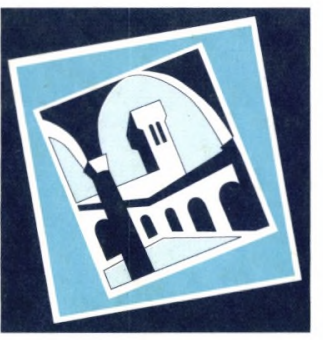

EUROPEAN UNIVERSITY INSTITUTE

The Robert Schuman Centre

\title{
The People, the Elites and \\ the Populist Challenge
}

\section{YVES MÉNY}

\section{JEAN MONNET CHAIR PAPERS}


European University Institute

|||||||||||||||||||||||||||||||||||||||||||||||||||||||||||||||

30001003687961 


\section{Jean Monnet Chair Papers}

Mény: The People, the Elites and the Populist Challenge 


\section{Jean Monnet Chair Papers}

47

\section{The Jean Monnet Chair}

The Jean Monnet Chair was created in 1988 by decision of the Academic Council of the European University Institute, with the financial support of the European Community. The aim of this initiative was to promote studies and discussion on the problems, internal and external, of European Union following the Single European Act, by associating renowned academics and personalities from the political and economic world to the teaching and research activities of the Institute in Florence. 


\title{
Jean Monnet Chair Papers
}

\author{
The People, the Elites \\ and \\ the Populist Challenge
}

Yves MÉNY

1998

The Robert Schuman Centre at the European University Institute 
All rights reserved.

No part of this paper may be reproduced in any form without permission of the author.

(C) Yves Mény

Printed in Italy in February 1998

European University Institute

Badia Fiesolana

I-50016 San Domenico (FI)

Italy 


\section{Table of Contents}

Introduction

p. 7

Constitutionalist supremacy

p. 10

What's wrong with present democratic arrangements?

p. 13

The populist challenge

p. 18

Conclusion

p. 22

Bibliography

p. 25

Biographical Note

p. 27 


\section{Introduction}

Democracy rests upon a rich and complex ambiguity. Because of the numerous and often discordant ways in which this word and idea have been interpreted, no such prototype exists, only variations of all kinds. Ralph Dahrendorf was right when, in addressing the people of Eastern Europe, he advocated the single, Popperian principle of the open society. "Within the constitution of liberty," wrote Dahrendorf, "a hundred paths lead forward and all are likely to mix elements of economic, political and social reforms in ways which offend the jurist. The key to progress is therefore not a complete alternative conception, a detailed master plan of freedom. Such plans are contradictions in terms and more likely to lead back to the closed society" (Dahrendorf, 1990, p.150). So, if we want to try to answer the central question of this meeting we have to introduce many qualifications into the debate. In other words, we must avoid falling into the trap of naïveté to which the true believers and zealots of democracy are prone. Their enthusiasm is somewhat comparable to the doctrinaire mind-sets of the former socialist countries. Looking at the experience of the recent democratisation process in these countries and the views expressed by the media, politicians and sometimes academics, I get the feeling that many Westerners were paraphrasing the famous Leninist definition of communism: socialism + electricity. After the fall of the Berlin wall, many observers also expressed a reductionist view, whereby democracy was simply considered to be: the market + elections.

Fortunately, democracy is much more than this. Yet there is no single definition of democracy. As indicated by the title of this conference, democracy is not a state of nature, it is a product of culture, un effet de l'art. Because of this cultural element, there is no such thing as a democratic model. There are democratic principles, whose implementation may vary from one polity to another: most Europeans would be reluctant to have elected judges while Americans would resist the idea of having only professional, tenured magistrates, for example.

But the paradoxes of Western democracy do not lie merely in its variety and diversity. Because of its sometimes very slow, sometimes very brutal, historical development, democratic systems necessarily incorporate elements and features of past non-democratic regimes. The Rechtsstaat and the Welfare State emerged and sometimes developed without any democratic purposes 
whatsoever in the mind of the rulers or their proponents. Corporatist traditions and institutions, as well as neo-corporatist practices, continue to flourish in most of continental Europe. Feudal or authoritarian rules and customs are still alive.

In other words, any democracy is a mix of pure democratic elements and liberal features. The democratic components or techniques are similar across countries and where there are variations, these differences tend to be limited: elections, referendums, electoral systems differ from country to country, but usually follow similar patterns. On the other hand, the liberal dimension introduces time and space variations which contribute to the specificity of each democratic system. All democratic systems are, in a way, democracies in the making. There is a certain amount of ignorance, even arrogance, in the old democracies' demands that the new-comers to the democratic club fulfill all the criteria of a largely mythical model. Indeed, even the so-called "old democracies" were able to achieve a satisfactory degree of democratisation only after many years, even centuries, of struggles, fights and hesitation. Rather than being an easy, fast track, the road to democracy has been painful, chaotic and long.

The story can be seen as the basic tension between these two complementary but conflicting elements, the democratic and the liberal, which together have constituted the pluralist political systems in the West (Leca, 1996). The conflicts concern the respective domain of each part and drawing the line between the two: how much is to be conceded to the democratic claim, how much reserved to the liberal creed? The nineteenth century and the beginning of the twentieth have revealed how representative government became more and more permeated by the democratic and less and less influenced by the liberal tradition. In Europe as well as in the United States, the political struggle has been over the conquest of universal suffrage (extension to all the adult male population, then to women, youth, and racial-ethnic minority groups), electoral systems' ensuring of fair representation and the elimination of political corruption.

The period from the Second World-War to the present has been characterised by a reverse trend. In continental Europe, the failure of democratic systems unable to face the challenges of the times or resist the manipulation of popular votes has convinced elites and constitution-makers to limit the excesses of the democratic element and to reinforce the liberal dimension. Popular input has been counterbalanced by various checks and balances, by procedures and institutions free of direct democratic control or intervention. The period 
from 1945 to 1990 was characterised by the rise and triumph of constitutionalism. It flourished first in Germany and Italy, then contaminated France, expanded into the former right-wing dictatorships of Southern Europe and reached its apex in the collapse of the socialist regimes and the intense activity of constitution-building in Eastern Europe. With a mix of success and failure, the democratic proselytisers exported the triumphant model to the rest of the word: South America, Asia, Africa. In a rather presumptuous way, some announced the end of history and claimed that there is in fact no alternative.

More recently, most of the democratic systems faced new challenges. Many labels have been placed upon this multifaceted phenomenon: globalisation, multi-culturalism, territorial autonomy, gender rights. It is difficult to evaluate their relative impact upon the functioning and sometimes very survival of democratic systems, nevertheless, they clearly reverse the post-war trend characterised by a persistent and still on-going process of elite domination under the cover of constitutionalism. It might be that the limits of this ideological and institutional preference for constitutionalism have been reached. Grass roots pressures in favour of a stronger democratic input have become more and more apparent in most Western political systems. This eruption of the people onto the political scene might be preparing the way for a new equilibrium between the democratic and liberal components. But re-balancing power, influence and institutions is always a risky operation. Too much constitutionalism jeopardises the democratic foundations of the regime by reducing the actual capacity of the people to influence and control political choices; too much direct input from the people can run the risk of majoritarian intolerance or dictatorial capture.

My argument is that constitutionalism has grown to its limits and that ruling elites are in crisis. They are facing a growing legitimacy problem resulting from the people's frustration and dissatisfaction with those who govern. More and more individuals, groups and emerging new leaders are coming to claim that they should have more say in the running of public affairs. You can call it popular will, the voice of the people, or public choice, if you see these phenomena in a positive light. On the other hand, if you don't like the interference of the masses in the elite club, it is easy to discredit it with the vague label: "populism". In fact, we can consider populism in the same way in which Italo Calvino speaks of his Barone dimezzato. Like the baron split in two during a fight, populism has two faces: one positive, which provides legitimacy to the democratic system, the Government of the people, by the people, for the people; the other negative, which might lead to exclusion, nationalism, xenophobia, and the denial of pluralistic values. 


\section{Constitutionalist supremacy}

Let me start with the supremacy of constitutionalism. This is a long story which began a few centuries ago. To use a common word in the Cold War period, the liberal problem is a problem of containment. How can a political system be built-up which can protect individuals and groups from each other? How can dictatorship by an individual or the domination of a group, even if a majority, be avoided? Benjamin Barber vividly illustrates the liberal dilemma in reminding us that:

Liberal democratic imagery seems to have been fashioned in a menagerie. It teems with beasts and critters of every description: sovereign lions, princely lions and foxes, bleating sheep and poor reptiles, ruthless pigs and ruling whales, sly polecats, clever coyotes, ornery wolves (often in sheep's clothing) and finally, in Alexander Hamilton's formidable image, all mankind itself is but one great Beast (Barber, 1984, 20).

Today, the victory of the liberal creed is complete not only because of its merits, but also because of the failures of the alternatives. Within the liberal democracies and countries aspiring to the Western model, constitutionalism has become the key value and catch-word. Following the disastrous experience of the twenties and thirties and the collapse of most infant democracies at that time, the post-1945 period has been characterised by a growing consensus on the fundamental virtues of constitutionalism. New mechanisms, such as the establishment of Constitutional Courts or independent Central Banks, have constituted the landmarks of this new era. Inspired by the American Madisonian realism adopted by most new constitutions of the post-war era and imitated by later followers, whether old or new democracies, constitutionalism has been successfully exported to the rest of the world. Americans and Europeans have competed in trying to sell their particular model, their set of institutions, their constitutional kit.

This constitutionalist bias has encountered some resistance here and there. The British still refuse to create a Supreme Court, even though their legislation is partly reviewed by the Luxembourg and Strasbourg courts. It took nearly ten years for Italy to put its Constitutional Court in place. And France was the most reluctant of all, for a long time refusing the gouvernement des juges and to sacrifice its republican traditions to the liberal, democratic view, a position supported not only by the French political class, but also by most lawyers and political scientists. 
This evolution of both values and institutions was accompanied and reinforced by the transformation of the political system: in the sixties and seventies there were still demands both for an extension of suffrage to new groups and lower levels of government (neighbourhoods, regions) and for a broader participation and involvement of the people outside the purely political sphere (for instance, in the universities and factories). The post-' 68 period was seen by many observers, including prestigious political scientists such as Crozier and Huntington, as endangering and undermining democracies by putting too much strain on the system (Crozier, Huntington and al., 1975). "Too much democracy kills democracy" was the message. Restraint of political participation was seen as a safeguard against an uncontrolled invasion of the masses into the world of the few. However, we might wonder whether or not these exuberant manifestations were not already a reaction against the capture of the democratic system by a narrow and self-perpetuating elite. At the very same time as some of our colleagues were expressing their fears about popular involvement, others were using new words and typologies to define particular European systems: Parteienstaat, Partitocrazia, Partitocratie. Without using the dramatic tones and at times reactionary motives of some of their famous predecessors, scholars and observers were reasserting the conclusions of Pareto, Mosca, Michels, Schumpeter and Ostrogorsky. But many, far from being worried about such a situation, insisted that democracy was not what people were told it was. Giovanni Sartori is probably the front-runner in this enterprise of Weberian disenchantment, but Popper's definition of democracy perhaps best captures the mood of the time: "Democracy is the word for something which does not exist" (Popper, 1988). So far, so good: the people elects representatives selected by parties and its role is limited to approving or rejecting the policies set-out by the ruling elites.

In recent years, this trend has been pushed even further: not only does the people not have much say in the political process, other than at election time, but entire policy areas have also been removed from political control. In the name of the battle against excessive politicisation, more and more domains, especially in the economic sphere, have been placed under the responsibility of non-elected persons usually chosen for their experience and/or expertise. Agencies, authorities, courts, QUANGO's, and various "semi-public" bodies, add a new dimension to Madisonian-style democracy. These new institutions have flourished everywhere nationally and have also expanded on the regional and international levels. New forms of legitimacy have emerged based on expertise, independence and apolitical/non-partisan involvement. It might also be interpreted as the confrontation between two different ways of conceiving of democracy: one puts more emphasis on political accountability and, in a last 
instance, popular control; the other believes that economics and markets are too important to be placed in the hands of politicians. As argued by the Court of Karlsruhe, for instance, monetary policy can be better ensured by an independent central bank than by "governments that are dependent on the short term of political forces".

Until recently, this evolution has received wide support amongst political, economic and social elites. Rather than counteract the progressive capture of the system by political parties through the institution of popular mechanisms of checks and controls, these new forms of division of power were usually preferred. There is probably only one exception to this general trend: the use of referenda by some countries with regards to the process of European integration. Academics in general have tended to favour this transformation, sometimes even contributing to the creation of new types of sacred cows. Having been one of the very few French academics to have advocated the transformation of the Conseil Constitutionnel into a true Constitutional Court, I am well-placed today to critically re-evaluate the benefits, but also the drawbacks, of such a general evolution.

It is probably my colleague and friend, Giandomenico Majone, who has expressed with the most enthusiasm and vigour the preference for a new type of decision-making based on expertise, independence and accountability (Majone, 1996). His reasoning is based on the distinction drawn in the nineteenth centry by the Swedish economist, Wicksell, between efficiency and redistribution and the need to tackle these two problems through different channels of decisionmaking. Efficient policies attempt to improve the welfare of all, or nearly all, while re-distributive policies improve the conditions of one group at the expense of others. Re-distributive policies, he argues, can only be achieved by majoritarian decisions, since unanimity is impossible. Efficient policies, where everyone can gain, should in principle be adopted by unanimity. Given the difficulty of achieving unanimity, the second-best solution can be the use of a decision taken by qualified majority or delegated to independent experts or non-majoritarian institutions. Majone does not deny that these modes of decision-making raise new legitimacy problems, but does underline the fact that these new criteria of legitimacy and accountability "are better adapted to the realities of an increasingly interdependent world than those derived from the traditional, but largely mythical model of pure majoritarian democracy". However, this evolution is far from being unanimously accepted either at national or regional/international levels. Referring to a ruling against the European Union's ban on meat produced with hormones, the European Agriculture 
Commissioner, Franz Fischler, questioned the "lack of democratic control" over this international board. This latest example is only one among many.

This academic debate in fact runs parallel to a more heated and political discussion in many countries. More and more people are dissatisfied with the way politics works and democracy functions. In many countries of continental Europe, there is a deep malaise and I would like to turn now to the examination of its symptoms and causes.

\section{What's wrong with present democratic arrangements?}

Charles Meier, in a recent contribution entitled: Democracy and its discontents (Meier, 1994), stressed that the present crisis of democracies is very different from the crisis of the seventies, which was about economic adjustment and the distribution of benefits. Today's crisis is more complex and possibly more dangerous as it tends to challenge not so much the outcome of democracy, but its very foundations. Let me first consider the symptoms of this crisis and then try to offer some kind of interpretation.

I suggest we focus on three elements of this Politikverdrossenheit: electoral volatility, partisan decartelization, and distrust of politicians.

First, the volatility of the electorate has become a general problem. It is an already vivid phenomenon in Eastern Europe, but can be explained both by the disillusions of the post-' 89 period and by the still unstable party system. In Western Europe, however, it is now clear that the old cleavages, such as class and religion, are less and less able to structure and explain electoral behaviour. The manifestations of this volatility are many: large and unstable variations in electoral participation, shifts in political preferences from one election to the other and voting against the parties of government and in favour of protest movements or radical parties. Even in countries such as Germany, Austria, or Italy, which have enjoyed high levels of voter turn-out and stable voting for the parties in government over the last fifty years, changes have been substantial and even dramatic, in the Italian case. The old allegiances have been weakened and new parties try to capture a floating electorate which is indifferent to political debates, skeptical about government and party programmes and critical of outcomes. If, as Fritz Scharpf argues, democracy can be tested both from an input and an output point of view, we have to recognise that the 
democratic input has become weaker and weaker and the democratic output less and less convincing in the eyes of the citizens (Scharpf, 1997).

Second, the instability of electoral behaviour has deeply transformed the situation of the political parties. During the seventies, eighties and early nineties, political parties in Western Europe underwent a progressive transformation, which Katz and Mair have analysed as a process of "cartelization". According to them, "we see the emergence of a new type of party, the cartel party, characterised by the interpenetration of party and state, and also by a pattern of inter-party collusion. In this sense, it is perhaps more accurate to speak of the emergence of cartel parties, since this development depends on collusion and co-operation between ostensible competitors, and on agreements which, of necessity, require the consent and co-operation of all, or almost all, participants"(Katz and Mair, 1996, p. 17).

This analysis is rather convincing and everyone can agree that "politics becomes a job rather than a vocation"(ib., p. 23). However, the picture they offer seems more in-line with the situation of the eighties than with that of the nineties. The present situation could be more accurately described as a crisis of the cartel and as an on-going process of decartelization. These processes are slowed-down or blocked by the resistance of the cartel parties or by particular institutional devices, such as the electoral systems. But it is clear that the unchallenged supremacy of those parties entrenched in the state is no longer accepted by a large segment of the population. By its very existence, the party cartel sets the conditions under which it can be challenged by those who feel excluded. Having reached its apex in the eighties, the cartel system today contributes to the de-legitimization of the democratic system itself, as more and more people tend to identify democracy with the way the members of the cartel run it. Katz and Mair sum-up this situation when they write that: "Democracy becomes a means of achieving social stability rather than social change and elections become 'dignified' parts of the Constitution" (ib., p. 22). But this opinion is a mild assessment of a phenomenon which might take-on more dramatic tones.

A third dimension of the problem has to do with the deterioration of the relationship between rulers and the ruled. In many countries, in the U.S. as well as in Europe, we observe the growth of dissatisfaction with politics, parties and politicians. It is revealing that expressions such as political class, oligarchy, establishment, nomenklatura have become part of everyday public discourse in talking about political elites. There are variations from country to country, but resentment against elites, the "establishment", those who govern, 
"they" versus "us", is emerging through opinion polls, by-elections, referenda and, last but not least, the formation and advance of protest parties of all kinds. If we again use Scharpf's distinction between input-oriented and outputoriented legitimizing beliefs, it would seem that both elements are in crisis: there is a lack of confidence in, a feeling of distrust of politicians and parties which is further accentuated by the incapacity of ruling elites to deliver to the people the policies to which they committed themselves in their electoral programmes.

One explanation often proposed in recent years has to do with the corruption scandals which have undermined many political systems over the last decade. Most of the European democracies have been confronted with illegal party financing, bribery and, in some cases, personal enrichment on the part of leading politicians. The confusion of markets and state, of public and private interest, of civil service and self-interest, contributes to the de-legitimization of political parties. Politicians' behaviour has further exacerbated this trend, in their denying the reality of significance of corruption and/or in their accusing the press and the judiciary of plotting against the representatives of the people. Another step in the downgrading of their public image has occurred in that the parties under inquiry have also made sure to involve their opponents in similar scandals. Unfortunately, demonstrating that all are sinners makes a meagre argument for the system. It simply comforts public opinion in its belief that all, or nearly all, politicians are rotten. Such scandals have had devastating effects in Spain, Greece, Italy and France. But other countries of Northern Europe, including Great Britain, have also fallen prey to this general lack of confidence in politicians and parties. Contrary to the situation in the thirties, democracy here, in most cases, has not been at stake. But the basic foundation of representative democracy, trust, has clearly been jeopardised.

However, we can wonder whether or not corruption has not simply been the acceleration of an already existing problem, that is, the more general weakening of political accountability. According to democratic theory, citizens have the right and the possibility to judge their government retrospectively through the electoral process, to sanction or reward it. However, we know by experience that these mechanisms are rather imperfect in their functioning. Wrong choices can be supported by the electorate and good leaders sanctioned for having made right ones: manipulation of public opinion through the media or clientelism can provide part of the explanation here. But most of the time, accountability is affected by problems such as the translation of individual choices into aggregate outcomes, or by the time-span problem. As everyone 
knows, the political cycle and the economic cycle do not always follow the same path. Accountability is, of course, imperfect, but the real problem today is the widespread perception by the public that politicians are not accountable. As pointed-out by our colleague José-Maria Maravall: "Most of the time, democratic accountability and political success, both in elections and in office, are not easily compatible" (Maravall, 1997).

Paradoxically, many political leaders have attempted to escape their responsibility and to avoid control by the media or judiciary by pretending to be accountable only to the people. Such leaders know only too well that democratic control is often imperfect, tardy, or easily dismissed by demagogic or clientelistic policies. Such manipulation of democratic instruments by politicians has reached its limits in recent years, when economic growth or generous distributive policies have provided easy instruments for buying voters' consent. The changes in citizens' behaviour have been rather dramatic: accusing politicians of being blind and deaf, citizens have vindicated themselves by voting against the parties and incumbents in power, rather than in favour of an ideology or programme.

Another explanation for the disillusionment and resentment of the people lies in the transformation of the policy process. During the post-war period, characterised by democratic reconstruction and rapid growth of the economy, there was a nearly perfect overlap between the identity space, the economic space and the political space. And where there was tension, for instance, from an ethnic, cultural or linguistic point of view, governments could mobilise economic and/or political resources in order to redress the situation. Today, these various spaces do not coincide and make credible or successful intervention by public authorities more difficult or even impossible.

First of all, there has been a general shift in public expectations. Fewer and fewer people believe in the capacity of the State to shape the society and promote the economy. The primacy of markets has been substituted for the imperium of the state in the mind of elites as well as of the people at-large.

Second, governments and parties have contributed to making the people aware of the new limits to public action in an era of globalisation and regionalisation. Without a doubt, many policies cannot be dealt with properly at the level of the polity, of the nation-state. It might be true that European integration, in the words of Alan Milward, has rescued the nation-state (Milward, 1992). But this rescue is not without problems, tensions and a loss of direction. Globalisation brings changes in scale, complexity and communi- 
cation, as Dahl points-out. The solution to this disharmony might be, as suggested by David Held, the constitution of a cosmopolitan order (Held and Archibugi, 1995). But for the time-being, there are more fears and frustrations than hopes and optimism in this transitional period. The cynicism of some elites might even exacerbate these feelings when new trends are intentionally exaggerated in order to put more pressure on groups and individuals reluctant to change: globalisation is often used as a quid pro quo to the Thatcherite formula: "there is no alternative". By pretending that some harsh policies are the only possible options, politicians have contributed not only to de-legitimising the European construction, which is attacked for its democratic deficit, but also to weakening the public's confidence in the government's capacity to act purposefully and efficiently. We may have gone too far in blindly accepting the inferiority of politics and the unquestionable supremacy of markets.

This reduction of the policy space has been further exacerbated by the tight control of the policy agenda by elites. As political programmes become more of the same and are all too often variations on the same theme, electoral competition can contribute to the setting of the political agenda only at the margins. What's worse is that too many politicians have, once in power, betrayed their commitments to the people or have done a political U-turn unacceptable to the electorate. Whether correct or not, there is a diffuse feeling amongst the population that real problems to not interest the politicians or that they are deaf and blind. This view might be slightly exaggerated since elected representatives have a vested interest in getting the support of their voters. However, the flows of the accountability process and the cartelisation of parties have indeed impeded or made more difficult the introduction of certain political and social problems onto the agenda. Important issues such as gender, environment, and migration, for example, have been brought onto the stage by minority groups or social movements. Most of the time, political leaders and parties have been late-comers in these areas. Despite slogans such as la politique autrement (politics in a different way), most politicians continue to practice politics as usual. And even when ruling elites do actually take-up issues raised by outsiders, they tend to reframe them according to their own interests and ideologies, giving the impression that they don't care about their electoral commitments.

All these factors have contributed over the past years to increasing the frustration and disillusionment of the people, opening new space for populist movements and charismatic leaders. 


\section{The populist challenge}

There is no clear definition of populism, partly because of the variations in the phenomenon over time and space and partly because of the loose way in which it is used, particularly in the media or by political actors. Thirty years ago, when Gellner and Ionescu attempted, along with some colleagues, to better understand what was populism, their conclusions remained cautious (Gellner and Ionescu, 1969). Some of the contributors, for instance, insisted that populism was not an ideology, but a syndrome. More recently, a French sociologist, Pierre-André Taguieff, wrote that if populism is "a real problem, it was also a conceptual mirage"(Taguieff, 1995). It is indeed true that populism has become a kind of catch-word loaded with contempt and prejudice. Latin American regimes, some leaders in former socialist countries as well as Ross Perot in the United States have been described as populist, as have the French Communist Party, the Italian Lega, the Front National, Margaret Thatcher, and Jacques Chirac. A recent issue of Die Zeit on "Populismus" in September 1997, illustrates the very flexible use of the concept in Germany as well.

This eclecticism in its application blurs the concept and might make one think it useless. However, the paradox still remains: why do we so venerate the people while hating populism? The answer to this question lies in the challenge populism poses to representative democracy. Populism pretends to be democratic, as indicated by its use of the famous motto: Government of the people, by the people, for the people. But its democratic claim contradicts the spirit, structure and modus operandi of the democracies as we know them, that is, representative democracies in which constitutionalism counter-balances the popular input.

Let me now turn to what constitutes the core of populism, to consider the context in which it develops and finally to assess the dangers and potentials of these movements.

Because of the very conditions of its emergence, populism defines itself first as an anti-system attitude or movement. Its reference point is always democracy, but not liberal democracy. Under these conditions, populism invariably finds itself in a rather negative position vis-à-vis the political system. It might be fighting an authoritarian regime, as in nineteenth century Russia, but most of the time populism grows within a democratic system considered to be corrupted and captured by unaccountable elites. Populism challenges democratic 
systems in the name of the people by declaring them undemocratic. The populist world is manichean: it pits the people against the elites, the community against outsiders or foreigners, individuals against groups and the bureaucracy, those with "common sense" against the intellectuals or ideologues.

Anti-elitism constitutes a key feature of populism. Political elites are accused of betraying their mandate, of looking-out only for their own self-interest rather than for the public good, of being both incompetent and inefficient. Even worse, they are often accused of corruption as well. Economic elites are seen as the instruments of big capital or foreign companies contributing to the collapse and death of the hard-working, efficient, competent, but fragile small companies, farmers and craftsmen. Bankers are especially despised as managers of an artificial economy making money on the backs of dedicated workers. The big cities, the stock markets and, most of the time, the capital city of the country symbolise this capture of power, money and influence by a limited few: Washington, Paris, Roma ladra, and Brussels (as the centre of Europe) have become symbolic scapegoats. The same distrust applies to intellectuals, considered either as being too far from the people or deprived of what is considered to be the major quality of the people: le bon sens (common sense).

This systematic and sometimes violent condemnation of elites implies giving the power back to the people and getting rid of so-called representatives. The slogan of the French Poujadistes in the late fifties: Sortez les sortants ("Oust the incumbents") is a reminder of the American populist motto at the end of the nineteenth century: "A gun behind the door". However, the populist attitude is ambiguous: bureaucrats are fiercely criticised, but the state is not always seen as an enemy. It can even be a shield against the internationalisation of finance or the globalisation of the economy. Populists hate lobbies and in particular banks or big firms, but they themselves mobilise groups such as farmers or tradesmen. Populists do not oppose the capitalist economy, but they usually dislike a deregulated, open market.

They advocate the power of the people, although not so much as individuals, but rather as members of a community, usually a national community. The community itself, however, might be an object of contention: most of the time, it is the nation, identified with those people who share an identity, a culture, a language. Sometimes, on the contrary, this community in the making identifies itself against the nation-state viewed as imposed and artificial. This is, for instance, the case of so-called Padania, the fake creature of the Italian Lega. Individuals are important as long as they fuse themselves with the community or, as Isaiah Berlin put it, as long as they believe in the values that constitute 
belonging to the same group or culture. This sublimation of individuals within the community explains why the concept of the people becomes an abstraction, its appeal resting mainly in the rejection of a perceived hierarchical order: the elites versus the people, "they" versus "us". But this anti-hierarchical attitude is somewhat contradicted by a fascination with the charismatic leader who, supposedly, embodies the features, claims and values of the people.

This set of values or aspirations has crucial implications for the rules and institutions of liberal democracy, the most important of which has probably to do with the concept of representation. Populists have an uneasy relationship with representation. On the one hand, they deeply dislike the representative system and the elites who run it. On the other hand, they are aware of the difficulty of running a community through direct involvement of the people. To solve this dilemma, populists propose a different view of what representation should be: first, representatives should be ideally as close as possible, as similar as possible, to the people they represent, not only politically, but, more importantly, sociologically. Identity is the key point of reference. Delegation is substituted for trust.

Second, according to populists, mediation through parties should be banned, given their propensity to defend their own interests instead of the interest of the people. This is a claim which has had broad appeal, as seen in the prohibition of party platforms or labels in many local elections in the U.S. and in persistent attacks against the traditional parties by populist groups such as the Lega, the Front National, the Austrian Freedom party, the Vlaams Blok or the Norwegian Progress Party. This claim has even contaminated the rhetoric of party leaders preferring to rely on their charisma than on party structure: Chirac, Reagan and Thatcher illustrate this contamination of the political debate by populist ideas. This anti-party attitude does not impede populists from organising themselves into some kind of party, under the direction of a strong leader. But these organisations pretend to be movements, not parties, and constantly have to face the risky process of institutionalisation which any movement must consider at some stage in its development.

From this initial predicament stem various institutional features: a preference for proportional representation as the least damaging system for recruitment of representatives; limitation of the length of terms in order to make elected officials more accountable; generalisation of elected offices being preferred to tenured bureaucratic appointments; de-politicisation of the political debate in the prohibition of party affiliation; the institution of mechanisms of direct democracy, such as initiatives, referendums and recalls; direct selection 
of the executive by the electorate, be it at national or local level; and, more recently and in line with public choice theory, a preference for territorial fragmentation and sectoral specialisation.

The populist impact, however, has also affected many other aspects, both old and new, of liberal democracy. It has contributed to a re-opening of the debate on citizenship, in particular with regards to the integration of foreigners or the right to vote for European citizens not living in their country of origin. It has sometimes even asserted the right of the people to make their own justice. It has given a new impulse to nationalistic and chauvinistic claims and contributed to the rise of xenophonbia and anti-minority attitudes. It helped challenge the principle of solidarity between rich and poor regions in the name of fiscal federalism or regional autonomy. The Lega wants to get rid of the Mezzogiorno and the Catalans and Basques don't want to pay for Galicia and Andalusia. In the most extreme cases, for instance, in France with the Front National, very sophisticated use of language allows leaders to evoke the worst memories of anti-Semitism and xenophobia without being overtly racist, and hence, subject to penal law.

I cannot agree more with Charles Meier when he writes that sooner or later "territorial populism tends to single-out as deviant and subversive those groups on the ethnic territory that stand for complexity and alternative principles of solidarity" (Meier, 1994, p. 61).

In its most extreme form, populism calls for exclusion or territorial division. When the enemy is the rest of the world: the transnational forces of capitalism, masons, intellectuals and lobbies, populism calls for the restoration of the nation and for exclusion of the impure elements, be they foreigners or simply "others". Democracy tends to be identified with a system based on identity, and solely on identity. Where a populist movement claims that it represents a specific identity within a polity, "territory becomes the one adjustable variable, since society cannot overcome its biological or cultural diversity".

Such politics of exclusion have many dimensions. One is illustrated by the Front National which has re-opened the black box of the past: the combination of authoritarian leadership with xenophobia, nationalism and cultural cleansing. The Austrian or Flemish versions are close to this model. Another variant can be found, for instance, in Italy, where the Lega has succeeded in creating a fake territory which exists only in the minds of a few excited activists. A third dimension, much older in its origins and more stable in its expression, is American populism. In spite of all the checks and balances within the U.S. 
system, it is not as innocuous as it may seem. A recent study published in the American Journal of Political Science shows that state or local referenda put on the ballot at the citizens' initiative may have a very negative impact on civil rights (Gamble, 1997). In her research, Barbara Gamble underlines the differential success rates of initiatives or popular referenda according to the subject matter in question. Only one-third of all initiatives and referenda were endorsed by the voters, yet three-quarters of those initiatives that would restrict civil rights were approved. In other words, those already in a minority position and affected by the rules of the representative system see their position further weakened by the use of hostile initiatives. Constitutional democracy is far from being perfect, but direct democracy also has many drawbacks and can produce many negative effects.

\section{Conclusion}

The tension between constitutionalism and populism is rooted in the fabric of our democracies. Because of the too numerous bad experiences we have gone through, we all know that pure democracy à la Rousseau is at best impossible and at worst, the recipe for dictatorship and totalitarianism. Yet we have probably gone too far in insulating the people from politics, except in rather conventional, ritualistic exercises such as elections. The populism which is once again appearing on the stage might be understood as a signal, as the call and need for major involvement of the civil society. Power can be confiscated by many different groups: parties, lobbies, bureaucrats, experts and markets. It is the role and function of democracy to strike the balance and to accommodate these various conflicting interests. Today, there is a disaffection with democratic values and practices and the feeling that politicians do not care about the real problems of the people and that the people's voice is not heard by those who govern. The problem cannot be solved simply through some kind of institutional engineering, such as the injection of instruments of direct democracy into the representative system. While this may help, it is not sufficient and could even produce negative consequences, as history has demonstrated. Nor is the Madisonian view that voting is a method for controlling officials sufficient either, because the mechanisms put in place do no work properly or the issues at stake escape popular control. If we accept, along with William Riker, that "all the elements of the democratic method are means to render voting practically effective and politically significant", then we should be attentive to the populist message (Riker, 1982). If the people believe that their vote is neither effective nor significant, the political system malfunctions. 
But populism, by closing itself within a more or less imagined community conceived of as being "the people" cannot provide the answer. There is a need for a new civic culture which allows for multiple allegiances and involvements, which combines the "right to roots" with the "right to options", which links the village and the world. We still have everything to learn and do concerning this new stage of democratic development. If we want to avoid resistance to globalisation (which does have certain negative effects on present democratic systems) turning tribalism and exclusion into an attractive alternative, democracy has to face the needs of this fin de siècle. Over the past two centuries, representative democracy has shown a remarkable capacity for adjustment and adaptation to the evolving needs and pressures of society, even if this transformation has often been more reactive than proactive. Today, the new challenge of globalisation produces a two-fold dilemma: on the one hand, it means the westernisation of the world thanks to a mix of technology, trade, market and human rights ideology; on the other hand, globalisation challenges the very foundations of the Western polities.

In this phase of world transformation, concepts and ideas, such as nation, state, citizen, the people, democracy are again and again discussed, re-elaborated and manipulated. Europe, in particular, is torn between its old national heritage, its variety of cultures, languages and political history, on the one hand, and its aspirations to construct a new polity which can be respectful of differences while also solving common problems in accordance with democratic principles. We should not aspire to the prevalent division in the U.S., where constitutionalism and Madisonian democracy prevail at the federal level, while populism often dominates at the State or local level. But the rise and development of populist claims in Europe should warn us that the socalled democratic deficit of the Union implies adjustment and change at the national level as well. Precisely because the nature of the problems democracy has to face are less state-based than ever, it would be foolish to maintain unchallenged the identification of democracy with a territory, a nation and its people. Let's not forget that when the French Revolution invoked the French people, it drew from the Normans and the Britons, the Provincials as well as the Basques, or, to put it in sociological terms used by Eugene Weber, it made peasants into Frenchmen (Weber, 1979).

For the time being, there is no such thing as an European people, but only a union of various peoples. Without hiding the immense difficulty inherent in making "a people of peoples", it seems to me that this is the only alternative we have to a world of tribes unified simply by a common market. The Maastricht decision of the Bundesverfassungsgericht unfortunately, in my 
view, goes in the wrong direction. By identifying the Demos with the heavy identity of the Volk, this decision not only impedes the necessary democratisation - in the full sense of the word - of the European Union, but also provides indirect support for the populist view that only the people of the nation can form the basis of a true democratic polity. Once again, like the democratic pioneers of the nineteenth century, we have to invent and build slowly and incrementally, through experimentation and learning, a democracy which is adapted to our time. Once again, the task is to reconcile popular will and gouvernement modéré, a sense of belonging and constitutional patriotism, legitimacy and efficiency, the rights of man and the rights of the people.

Let me give the last word to Montesquieu who was not a democrat but made an immense contribution to the foundation of pluralistic democracy:

Je suis homme avant d'être français parce que je suis nécessairement homme et que je ne suis français que par hasard (Montesquieu, 1941, 9). 


\section{Bibliography}

Barber, B. (1984) Strong Democracy - Participatory Politics for a New Age, Berkeley, University of California Press.

Crozier, M., Huntington, S. and al. (1975) The Crisis of Democracy: Report on the Governability of Democracies to the Trilateral Commission, New York, NY University Press.

Dahrendorf, R. (1990) Reflections on the Revolution in Europe, London, Chatto and Windus.

Gamble, Barbara S. (1997) "Putting Civil Rights to a Popular Vote", American Journal of Political Science, vol. $41, \mathrm{n}^{\circ} 1$, January.

Held, D. and Archibugi, D. (1995) Cosmopolitan Democracy: an Agenda for a New World Order, Oxford, Polity Press.

Ionescu, G. and Gellner, E., (1969) Populism. Its Meanings and National Characteristics, London, McMillan.

Katz, R. and Mair, P. (1996) "Changing Models of Party Organization - The Emergence of the Cartel Party", Party Politics, vol. 1, $\mathrm{n}^{\circ} 1$.

Leca, J. (1996) "La démocratie à l'épreuve des pluralismes", Revue française de science politique, vol. $46, \mathrm{n}^{\circ} 2$, avril.

Majone, G. (1996) Temporal Consistency and Policy Credibility: Why Democracies Need Non-Majoritarian Institutions, EUI Florence, Working Paper $\operatorname{RSC} n^{\circ} 96 / 57$.

Maravall José M. (1997) Surviving Accountability, EUI Florence, Jean Monnet Chair Paper RSC n 97/46.

Meier C. (1994) Foreign Affairs, ${ }^{\circ} 4$, July-August.

Milward, Alan S. (1992) The European Rescue of the Nation State, London, Routledge. 
Montesquieu C. (1941) Cahiers, I, Paris, Grasset.

Popper, K. (1988) The Economist, 23 April.

Riker William H. (1982), Liberalism against Populism: A Confrontation between the Theory of Democracy and the Theory of Social Choice, San Francisco, Freeman.

Scharpf Fritz W. (1997) Games Real Actors Play: Actor-centred Institutionalism in Policy Research, Boulder, Westview P.

Taguieff Pierre-A. (1995) "Political Science Confronts Populism: From a Conceptual Mirage to a Real Problem", Telos, $\mathrm{n}^{\circ} 103$.

Weber E., (1979) Peasants into Frenchmen. The Modernization of Rural France, London, Chatto\&Windus. 


\section{Biographical Note}

Professor YVES MÉNY is Director of the Robert Schuman Centre. Since entering the academic world in 1974, Professor Mény has occupied teaching positions in Rennes, the European University Institute, Paris II, and prior to the directorship of the Schuman Centre, he was Professor at the Institut d'Études Politiques, Paris. As a visiting professor, he has spent study periods at the universities of Bologna, Madrid, New York, Rome and Washington. His research and publications cover varied subject areas, including the reform of administration, regional questions (regionalisation, reform of local authorities), the crisis of the European iron and steel industry, comparative politics and policies, the French political system, and the corruption in France and the Western Democracies. His latest work addresses the issue of populism in Europe. 


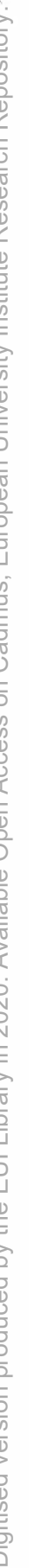




\section{Jean Monnet Chair Papers}

\section{European University Institute, Florence}

\section{CHRISTOPH BERTRAM/Sir \\ JULIAN BULLARD/ \\ LORD COCKFIELD/ Sir DAVID \\ HANNAY/MICHAEL PALMER \\ Power and Plenty? From the \\ Internal Market to Political and \\ Security Cooperation in Europe, April 1991,pp. 73}

\section{ROBERT GILPIN}

The Transformation of the International Political Economy, April 1991, pp.27

\section{EDMOND MALINVAUD}

Macroeconomic Research and European Policy Formation, April 1991, pp. 58

\section{SERGIO ROMANO}

Soviet Policy and Europe Since Gorbachev, April 1991, pp. 25

\section{BERNT VON STADEN}

The Politics of European Integration, April 1991, pp. 33

\section{HELGA HAFTENDORN} European Security Cooperation and the Atlantic Alliance, July 1991, pp. 42

\section{THOMAS}

ANDERSSON/STAFFAN

BURENSTAM LINDER

Europe and the East Asian

Agenda,

October 1991, pp. 87
8. ROGER G. NOLL

The Economics and Politics of Deregulation, October 1991, pp. 89

9. ROBERT TRIFFIN IMS International Monetary System - or Scandal?, March 1992, pp. 49

10. EGON BAHR

From Western Europe to Europe, June 1992, pp. 42

\section{HELGE HVEEM}

The European Economic Area and the Nordic Countries - End Station or Transition to EC Membership?, June 1992, pp. 21

12. ERIC STEIN

Post-communist Constitutionmaking: Confessions of a Comparatist (Part I), August 1992, pp. 63

13. CAROLE FINK 1922/23 From Illusion to Disillusion, October 1992, pp. 19

\section{LOUIS H. ORZACK}

International Authority and Professions. The State Beyond The Nation-State, November 1992, pp. 47 
15. VLADIMIR M. KOLLONTAI

Economic Reform in Russia,

November 1992, pp. 43

16. RYUTARO KOMIYA

Japan's Comparative Advantage in the Machinery Industry: Industrial Organization and Technological Progress, October 1993, pp. 60

17. GIULIANO AMATO

Problems of Governance - Italy and Europe: A Personal Perspective,

October 1994, pp. 39

18. JEREMY RICHARDSON

The Market for Political

Activism: Interest Groups as a

Challenge to Political Parties,

November 1994, pp. 37

19. RICHARD B. STEWART

Markets versus Environment?,

January 1995, pp. 53

20. JOHN GERARD RUGGIE

At Home Abroad, Abroad at

Home: International Liberaliza-

tion and Domestic Stability in the

New World Economy,

February 1995, pp. 64

\section{DAVID VOGEL}

The Relationship Between Environmental and Consumer Regulation and International Trade, February 1995, pp. 44

\section{JOHN WILLIAMSON}

Proto-EMU as an Alternative to Maastricht, March 1995, pp. 20
23. THOMAS C. HELLER

Joint Implementation and the

Path to a Climate Change

Regime,

March 1995, pp. 49

24. NORMAN SCHOFIELD

Modelling Political Order in

Representative Democracies,

June 1995, pp. 38

25. VOJIN DIMITRIJEVIC

The Fate of Non-Members of

Dominant Nations in Post-

Communist European Countries,

June 1995, pp. 34

\section{HORST SIEBERT}

Eastern Germany in the Fifth

Year. Investment Hammering in the Basement?,

September 1995, pp. 45

27. CAROL HARLOW

Codification of EC

Administrative Procedures?

Fitting the Foot to the Shoe or the

Shoe to the Foot,

September 1995, pp. 34

28. FRITZ W. SCHARPF

Negative and Positive Integration in the Political Economy of

European Welfare States,

November 1995, pp. 44

29. VINCENT WRIGHT

Industrial and Banking

Privatization in Western Europe:

Some Public Policy Paradoxes,

November 1995, pp. 40 
30. ROBERT O. KEOHANE

Local Commons and Global

Environmental Interdependence:

Tragedy of the Commons or

Opportunity for Institutions?,

November 1995, pp. 21

\section{SABINo CASSESE}

The Difficult Profession of

Minister of Public

Administration,

December 1995, pp. 31

32. MANCUR OLSON JR.

The Varieties of Eurosclerosis:

The Rise and Decline of Nations since 1982,

December 1995, pp. 37

\section{ROD A.W. RHODES}

Towards a Postmodern Public

Administration: Epoch,

Epistemology or Narrative?,

December 1995, pp. 49

34. MARTIN SHAPIRO

Independent Agencies:

US and EU,

April 1996, pp. 31

\section{S ASKIA S ASSEN}

The De-Facto Transnationalizing of Immigration Policy, April 1996, pp. 36

36. JOSÉ MARÍA MARAVALL The Outcomes of Democracy, April 1996, pp. 53

\section{PIERRE ROSANVALLON}

État-providence et citoyenneté sociale,

September 1996, pp. 27
38. PETER B. KENEN

Sorting Out Some EMU Issues, October 1996, pp. 36

39. En hommage à ÉMILE NOËL, December 1996, pp. 21

40. TOMMASO PADOASCHIOPPA

The Genesis of EMU: A

Retrospective View,

December 1996, pp. 21

41. GIL CARLOS RODRIGUEZ

IGLESIAS

Le pouvoir judiciaire de la

Communauté européenne au

stade actuel de l'évolution de l'Union,

December 1996, pp. 27

42. WOLFGANG STREECK

Citizenship under Regime

Competition: The Case of the

"European Works Councils",

April 1997, pp 49

43. NiCOLE QUESTIAUX

Le Conseil d'État français et la norme communautaire:

l'hybridation en tant que

technique juridique,

May 1997, pp 25

44. PAUL PIERSON

Increasing Returns, Path

Dependence and the Study of

Politics,

June 1997, pp 47

45. ECKARD REHBINDER

Environmental Agreements -

A New Instrument of

Environmental Policy, August 1997, pp 37 
46. JOSÉ MARÍA MARAVALL

Surviving Accountability,

October 1997, pp 46

47. YVES MÉNY

The People, the Elites and the

Populist Challenge,

February 1998, pp 27 
(1) 